\title{
Pengaruh Penganggaran Partisipatif Terhadap Budget Slack dengan Sikap sebagai Variabel Moderating
} Anggia Dini Syahrir ${ }^{1}$

${ }^{1}$ Fakultas Ekonomi Dan Bisnis Universitas Brawijaya, Veteran Street, Ketawanggede, Lowokwaru, Malang, 65145, East Java, Indonesia

Key words:

Participative budgeting

Attitude

Budget slack

\begin{abstract}
A B S T R A C T
This study examines the effects of participative budgeting to the budget slack to be moderated by the attitude. This study used a sample of 140 individuals ranging from Head of Work Unit (SKPD) and Head of the Southeast Sulawesi provincial government. The analytical method used in this study is Partial Least Square (PLS) with SmartPLS as a means of statistical tests. The results showed that participative budgeting significant negative effect on the budget slack. The higher participation in preparing the budget, budget slack generated would be lower. As for the attitude of participative budgeting strengthened the influence of the budget slack. This indicates that the participant is responsible for the task in hand in preparing the budget so the attitude is able to strengthen the influence of participatory budgeting to budget slack.
\end{abstract}

\begin{abstract}
A B S T R A K
Studi ini menguji pengaruh penganggaran partisipatif terhadap budget slack dengan dimoderasi oleh sikap. Penelitian ini menggunakan sampel sejumlah 140 individu mulai dari Kepala Satuan Kerja Perangkat Daerah (SKPD) dan Kepala Bagian pada Pemerintah Provinsi Sulawesi Tenggara. Metode analisis yang digunakan dalam penelitian ini adalah Partial Least Square (PLS) dengan SmartPLS sebagai alat uji statistik. Hasil penelitian menunjukkan bahwa penganggaran partisipatif berpengaruh negatif signifikan terhadap budget slack. Semakin tinggi partisipasi dalam menyusun anggaran, budget slack yang dihasilkan akan semakin rendah. Adapun sikap semakin memperkuat pengaruh penganggaran partisipatif terhadap budget slack. Hal ini menunjukkan bahwa partisipan bertanggungjawab atas tugas yang diembannya dalam menyusun anggaran sehingga sikap mampu memperkuat pengaruh penganggaran partisipatif terhadap budget slack.
\end{abstract}

\section{PENDAHULUAN}

Anggaran menjadi suatu alat yang sangat penting dalam melakukan perencanaan dan pengendalian jangka pendek yang efektif dalam suatu organisasi (Anthony dan Govindarajan, 2001). Anggaran dibutuhkan dalam melakukan perencanaan dan pengendalian dalam rangka mencapai tujuan yang ingin dicapai oleh suatu organisasi, termasuk juga organisasi pemerintah atau sektor publik. Pemerintah daerah di Indonesia membutuhkan anggaran sebagai kebutuhan strategis dalam penyelenggaraan pemerintahan. Perencanaan anggaran yang dilakukan oleh pemerintah daerah dilakukan untuk dapat mengetahui kemampuan pemerintah daerah dalam menyelenggarakan urusan pemerintahan. Hal inilah yang kemudian membuat anggaran menjadi instrument terpenting dalam penyelenggaraan pemerintahan daerah.

Penelitian ini mengangkat permasalahan tentang budget slack atau kesenjangan anggaran pada pemerintah daerah. Fenomena perilaku budget slack pada pemerintah daerah terjadi karena adanya perbedaan potensi dengan target anggaran pendapatan, perbedaan potensi pendapatan dengan target anggaran pendapatan mengindikasikan terjadinya perilaku individu merendahkan target pendapatan untuk 
memudahkan dalam pencapaian anggaran Pemerintah Daerah. Artinya bahwa terjadinya slack dalam anggaran ditimbulkan oleh adanya perilaku individu untuk mengupayakan membuat anggaran yang dirasa lebih mudah untuk dapat dicapai, serta aman ketika anggaran tersebut dipertanggungjawabkan (Rahim, et.al., 2013; Maskun 2009; Fitri, 2004).

Berdasarkan data APBD yang didapatkan mengenai indikasi terjadinya budget slack pada instansi pemerintah Provinsi Sulawesi Tenggara tahun 2013 dan 2014 dapat dilihat pada tabel sebagai berikut:

Tabel 1. Potensi danTarget Pandapatan Asli Daerah Provinsi Sulawesi Tenggara, 2013-2014

\begin{tabular}{lllll}
\hline Tahun & \multicolumn{2}{c}{2013} & \multicolumn{2}{c}{2014} \\
\hline $\begin{array}{l}\text { Uraian } \\
\text { Items }\end{array}$ & $\begin{array}{c}\text { Potensi } \\
(\mathrm{Rp})\end{array}$ & $\begin{array}{c}\text { Target } \\
(\mathrm{Rp})\end{array}$ & $\begin{array}{c}\text { Potensi } \\
(\mathrm{Rp})\end{array}$ & $\begin{array}{c}\text { Target } \\
(\mathrm{Rp})\end{array}$ \\
\hline Pajak & 408.107 .1 & 375.684 .8 & 467.499 .0 & 457.838 .3 \\
Daerah & 45.035 & 54.808 & 81.165 & 79.672 \\
\hline Retribu & 599.942 .7 & 570.190 .9 & 23.044 .02 & 18.244 .03 \\
si & 51.257 & 05.024 & 9.555 & 4.338 \\
\hline Hasil & & & & \\
Pengel & & & & \\
olaan & & & & \\
Kekaya & 23.843 .79 & 23.821 .67 & 24.000 .00 & 23.315 .54 \\
an & 4.855 & 9.810 & 0.000 & 0.453 \\
Daerah & & & & \\
yang & & & & \\
Dipisa & & & & \\
hkan & & & & \\
\hline Lain- & & & & \\
lain & 78.887 .49 & 54.991 .19 & 100.544 .7 & 87.647 .79 \\
PAD & 0.677 & 3.926 & 96.794 & 4.304 \\
yang & & & & \\
Sah & & & & \\
\hline Sumber : Dilah & & & \\
\hline
\end{tabular}

Sumber : Diolah dari data APBD, 2016

Berdasarkan tabel 1 di atas menunjukkan data history Pendapatan Asli Daerah (PAD) Provinsi Sulawesi Tenggara selama dua tahun terakhir. Pada tabel tersebut terlihat bahwa setiap tahunnya, adanya perbedaan potensi dengan target pendapatan. Dari data tersebut menunjukkan adanya budget slack karena terlihat dari setiap tahunnya target pendapatan lebih rendah dibanding dengan potensi yang dimiliki. Indikasi dalam data historis ini semakin memperkuat budget slack yang diciptakan selama penyusunan anggaran.

Menurut Halim dan Abdullah (2006) dan Fozzard (2001) mengatakan bahwa perilaku slack tersebut terjadi karena hubungan agensi (hubungan atasan-bawahan) menginginkan posisi yang relatif aman dan nyaman dalam melaksanakan tugas dan fungsinya. Sebagaimana dijelaskan dalam teori agensi mengenai bagaimana atasan mendelegasikan pekerjaan kepada bawahan dan bawahan melaksanakan tugas untuk mencapai kepentingan atasan, kemudian hubungan antara atasan dan bawahan menimbulkan masalah atau yang disebut agency problem. Permasalahan ini muncul karena adanya keterlibatan dua pihak, yaitu atasan yang memiliki otoritas melakukan tindakan-tindakan untuk mengendalikan perilaku bawahan agar anggaran yang disusun memenuhi kepentingan dapat dipertanggungjawabkan dan bawahan yang menerima pendelegasian dari atasan untuk terlibat dalam penyusunan anggaran untuk menentukan anggaran yang sesuai dengan sasaran dan target yang ingin dicapai (Douglas dan Weir, 2000; Carr dan Brower, 2000; Lupia dan McCubbins, 1994). Begitu pula dalam pemerintah daerah, terutama pada saat menyampaikan anggaran sebagai dasar untuk menilai program, target, dan anggaran yang ingin dicapai sebagai ukuran keberhasilan pelaksanaan anggaran (Smith dan Bertozzi, 1998; Lupia dan McCubbins, 2000).

Proses penyusunan anggaran melibatkan banyak pihak, mulai dari pejabat tingkat atas maupun bawah mempunyai dampak langsung terhadap perilaku individu, terutama bagi orang yang terlibat langsung dalam proses penyusunan anggaran (Yuhertiana, 2004). Partisipasi dalam proses penyusunan anggaran memperkuat harapan penerimaan reward yang berkaitan dengan pencapaian anggaran sehingga memberikan kesempatan kepada bawahan untuk melakukan tawar menawar anggaran yang lebih mudah dicapai (Schiff dan Lewin, 1970; Lowe dan Shaw, 1968).

Penganggaran partisipatif sering dihubungkan dengan budget slack. Anggaran partisipatif merupakan proses kerja sama antara manajer tingkat bawah selaku agen dan manajer tingkat atas selaku prinsipal dalam pengambilan keputusan yang berkaitan dengan penganggaran daerah. Beberapa penelitian terdahulu yang menguji pengaruh penganggaran partisipatif terhadap budget slack masih menunjukkan hasil yang beragam. Young (1985) dan Lukka (1988), telah menguji secara empiris bahwa penganggaran partisipatif memiliki pengaruh positif dan dapat meningkatkan terjadinya budget slack, karena individu-individu berpartisipasi dalam penyusunan anggaran dan mempunyai pengaruh terhadap target anggaran tersebut.

Mahadewi (2014) melakukan penelitian pada Pemerintah Kota Denpasar. Bukti empiris 
dari studi Mahadewi (2014) menunjukkan bahwa partisipasi anggaran berpengaruh positif terhadap budget slack. Hasil penelitian ini menunjukan bahwa semakin tinggi tingkat partisipasi, maka bawahan diberi kesempatan untuk menciptakan sendiri standar untuk menilai kinerja mereka, dan mereka akan memiliki kecenderungan untuk menggunakan kelebihan akan pengetahuan yang mereka miliki untuk menciptakan senjangan anggaran. Dengan adanya partisipasi bawahan dalam menyusun anggaran, maka bawahan merasa terlibat dan harus bertanggung jawab pada pelaksanaan anggaran sehingga diharapkan bawahan dapat melaksanakan anggaran dengan baik. Hasil ini didukung oleh Triadhi (2014) yang melakukan penelitian di pemerintah Provinsi Bali bahwa semakin tinggi partisipasi bawahan dalam penyusunan anggaran maka budget slack yang terjadi akan semakin tinggi pula. Artinya bahwa apabila bawahan diberikan kesempatan untuk berpartisipasi dalam penyusunan anggaran, membuat manajer bawahan akan berperilaku disfungsional karena dengan dasar bahwa anggaran digunakan sebagai dasar penilaian kinerja mereka. Temuan ini konsisten dengan temuan Lestari dan Putri (2015), Noch (2006), Hafsah (2005), Sudarba (2010), Pratama (2013), dan Triadhi (2014) dalam penelitiannya menunjukkan bahwa dengan semakin tinggi partisipasi anggaran akan meningkatkan budget slack yang terjadi di lingkungan pemerintah daerah sehingga bawahan yang berpartisipasi dalam penyusunan anggaran akan melakukan budget slack.

Hasil penelitian diatas tidak konsisten dengan hasil penelitian Nouri dan Parker (1996) menemukan bukti empiris keterlibatan yang tinggi dalam proses penyusunan anggaran cenderung menurunkan budget slack. Beberapa peneliti juga menemukan adanya pengaruh negatif penganggaran partisipatif terhadap budget slack diantaranya Merchant (1985), Onsi (1973), Dunk (1993), Fitri (2004), Supanto (2010), Desmiyawati (2009), Kartika (2010) dan Firmansyah (2015). Hal ini ketika partisipasi tinggi maka senjangan anggaran menjadi rendah dan sebaliknya. Adanya keterlibatan (partisipasi) yang besar dalam proses penganggaran dapat menurunkan budget slack, artinya keterlibatan/partisipasi anggaran tersebut mampu mengontrol tindakan individu lainnya karena fungsi pengawasan anggaran semakin meningkat.

Perbedaan beberapa hasil penelitian di atas menunjukkan sebuah fenomena yang menarik karena adanya perbedaan hasil temuan tentang penganggaran partisipatif terhadap budget slack. Bukti empiris penelitian belum konsisten bahwa penganggaran partisipatif berpengaruh terhadap budget slack. Hal ini terbukti dari perbedaan temuan penelitian-penelitian, baik pada sektor privat maupun sektor publik. Dari alasan tersebut maka perlu diuji kembali untuk memperkuat dukungan temuan sebelumnya. Khusus studi dalam bidang akuntansi sektor publik yang masih kurang adalah penelitian mengkaji pengaruh penganggaran partisipatif terhadap budget slack di pemerintahan daerah.

Hasil penelitian yang berlawanan ini mungkin karena ada faktor lain yang juga berpengaruh terhadap hubungan antara penganggaran partisipatif dan budget slack (Latuheru, 2005) sehingga dari hasil-hasil penelitian tersebut dapat disimpulkan bahwa dorongan pimpinan (atasan) dan individu yang terlibat dalam penyusunan anggaran untuk melakukan budget slack masih tetap belum dapat disimpulkan penyebabnya. Faktor-faktor yang dapat memengaruhi hubungan penganggaran partisipatif terhadap budget slack dapat berasal dari individu yang bersangkutan. Dalam penelitian ini diajukan variabel sikap untuk menyelidiki pengaruh variabel tersebut terhadap hubungan antara penganggaran partisipatif dan budget slack.

Ajzen (2005) mendefinisikan sikap sebagai suatu disposisi untuk merespon secara positif atau negatif suatu perilaku. Sikap terhadap perilaku ditentukan oleh belief tentang konsekuensi dari sebuah perilaku, yang disebut sebagai behavioral beliefs. Menurut Ajzen (2005) setiap behavioral beliefs menghubungkan perilaku dengan hasil yang bisa didapat dari perilaku tersebut. Sikap terhadap perilaku ditentukan oleh evaluasi individu mengenai hasil yang berhubungan dengan perilaku dan dengan kekuatan hubungan dari kedua hal tersebut.

Beberapa penelitian sebelumnya menemukan bahwa telah terjadi perilaku individu dalam menciptakan budget slack di pemerintah daerah (Su dan Ni, 2013; Rahim, et al., 2013: Yuhertiana, 2004 dan 2011; Maskun, 2009; Falikhatun, 2005 dan 2007; Fitri, 2004; Suhartono dan Solichin, 2007).

$\mathrm{Su}$ dan Ni (2013) yang melakukan penelitian dengan mengambil objek pada supervisor departemen manufaktur dalam daftar perusahaan di Taiwan, dalam penelitiannya menemukan bahwa partisipasi anggaran dapat mengurangi senjangan anggaran melalui peningkatan sikap sehingga apabila individu memiliki niat positif dalam penyusunan anggaran 
maka senjangan anggaran akan berkurang. Shciff and Lewin (1968) melaporkan hasil penelitiannya bahwa budget slack merupakan perilaku yang disadari dan disengaja oleh manajemen selama proses penganggaran. Kemudian Merchant (1981) juga melakukan sebuah penelitian mengenai pengaruh perilaku manajerial terhadap penganggaran. Temuan penelitiannya menunjukkan bahwa perilaku terhadap penganggaran memiliki hubungan yang tinggi. Hal ini dikarenakan oleh keterlibatan manajer yang sangat besar dalam proses penganggaran mengakibatkan manajer merasa pencapaian anggaran lebih penting dan menjadi hal yang utama.

Huang dan Chen (2009) melakukan penelitian survei terhadap individu (manajer) di Taiwan untuk menguji kecenderungan individu membuat senjangan anggaran dalam konteks perilaku. Bukti empiris menunjukkan bahwa persepsi positif sikap "attitude" individu, yaitu sikap baik yang dimiliki oleh individu dalam proses penyusunan anggaran dapat mengurangi terjadinya senjangan anggaran. Hasil temuan ini konsisten dengan temuan Onsi (1973) dan Kren (2003) bahwa sikap individu berpengaruh terhadap senjangan anggaran.

Berdasarkan fenomena yang telah dijelaskan tersebut, adapun rumusan masalah yang diajukan dalam penelitian ini adalah (1) Apakah penganggaran partisipatif berpengaruh terhadap budget slack di Instansi Pemerintah Provinsi Sulawesi Tenggara?, (2) Apakah sikap memoderasi penganggaran partisipatif tehadap budget slack di Instansi Pemerintah Provinsi Sulawesi Tenggara?

\section{RERANGKA TEORI DAN HIPOTESIS \\ Teori Agensi}

Dalam teori agensi dijelaskan hubungan agensi terjadi ketika satu atau beberapa pihak (principal) mempekerjakan pihak lain (agent) dengan tujuan mendelegasikan tanggung jawab kepada agent (Baiman, 1990). Hak dan tanggung jawab principal dan agent tertuang dalam sebuah perjanjian (kontrak) yang telah disepakati kedua belah pihak. Teori agensi berasumsi bahwa manusia adalah makhluk yang rasional dan berusaha untuk memaksimalkan utilitasnya (Davis et al., 1997; Baiman, 1990).

Teori agensi dalam penelitian bertujuan untuk menjelaskan hubungan atasan-bawahan dalam proses penyusunan anggaran, terutama ketika bawahan dalam menargetkan anggaran cenderung membuat anggaran yang menyebabkan terjadinya budget slack. Teori agensi menjelaskan fenomena hubungan atasan bawahan dalam penyusunan anggaran terutama ketika bawahan membuat target anggaran yang akan dicapai (Nouri dan Parker, 1996). Menurut teori agensi keterlibatan bawahan dalam penyusunan anggaran memengaruhi target anggaran yang akan dicapai, artinya bawahan mempunyai kesempatan yang lebih besar untuk melakukan budget slack untuk tujuan mempermudah pencapaian target anggaran tersebut (Lukka, 1988).

Teori keagenan menganalisis susunan kontraktual di antara dua atau lebih individu, kelompok, atau organisasi. Salah satu pihak (principal) membuat suatu kontrak, baik secara implisit maupun eksplisit, dengan pihak lain (agent) dengan harapan bahwa agent melakukan pekerjaan seperti yang diinginkan oleh prinsipal. Menurut Lane (2003a) teori agensi dapat diterapkan dalam organisasi publik. Lane menyatakan bahwa negara demokrasi modern didasarkan pada serangkaian hubungan prinsipalagent (Lane, 2000:12-13; Moe, 1984) yang menjelaskan konsep ekonomika organisasi sektor publik menggunakan teori agensi. Bergman dan Lane (1990) menjelaskan bahwa hubungan principal-agent merupakan pendekatan yang sangat penting untuk menganalisis komitmen komitmen kebijakan publik.

Teori agensi dalam kerangka akuntansi sektor publik dapat diimplementasikan. Dikatakan oleh Halim dan Abdullah (2006) bahwa di pemerintah daerah terdapat hubungan dan masalah keagenan, yaitu; hubungan eksekutif dan legislatif, hubungan agensi antara legislatif dan publik, dan hubungan agensi dalam penyusunan anggaran daerah di Indonesia, yang pada gilirannya bermuara pada teori agensi. Teori agensi merupakan salah satu dasar dalam ilmu anggaran dan akuntansi. Analisis hubungan dan masalah agensi di pemerintahan daerah mencakup dari keakurasian anggaran hingga pada analisis angkaangka laporan keuangan pemerintah daerah.

\section{Theory of Planned Behavior}

Theory of Planned Behavior (TPB) atau teori perilaku terencana merupakan pengembangan lebih lanjut dari theory of reasoned action (TRA). Ajzen (2005) menambahkan konstruk yang belum ada dalam theory of reasoned action (TRA), yaitu kontrol perilaku persepsian (perceived behavioral control). Konstruk ini ditambahkan dalam upaya 
memahami keterbatasan yang dimiliki individu dalam rangka melakukan perilaku tertentu. TPB menjelaskan mengenai perilaku spesifik dalam diri individu. Teori ini memprediksi dan menjelaskan perilaku manusia dalam konteks tertentu. Penelitian ini menggunakan pendekatan TPB karena dalam proses penyusunan anggaran, partisipan memiliki perilaku yang berbeda-beda dalam menyusun anggaran. Perilaku tersebut dapat tercermin dari sikap individu.

Sikap terhadap suatu perilaku dipengaruhi oleh keyakinan bahwa perilaku tersebut akan membawa kepada hasil yang diinginkan atau tidak diinginkan. Sikap sendiri dipengaruhi oleh keyakinan akan hasil dari tindakan yang telah lalu. Keyakinan mengenai perilaku apa yang bersifat normatif (yang diharapkan oleh orang lain) dan motivasi untuk bertindak sesuai dengan harapan normatif tersebut membentuk norma subjektif dalam diri individu. Kontrol perilaku ditentukan oleh pengalaman masa lalu dan perkiraan individu mengenai seberapa sulit atau mudahnya untuk melakukan perilaku yang bersangkutan (Anwar, 1995).

Berdasarkan uraian di atas, kerangka konsep penelitian dapat digambarkan pengembangan model penelitian dalam konteks teori agensi dengan menyatukan teori psikologi yaitu teori planned behaviour. Dalam gambar 1 diuraikan hubungan teori agensi untuk menjelaskan individu membuat slack dalam anggarannya, ketika bawahan memiliki kesempatan berpartisipasi dalam penyusunan anggaran dapat meningkatkan komitmen individu untuk mengurangi slack anggaran.

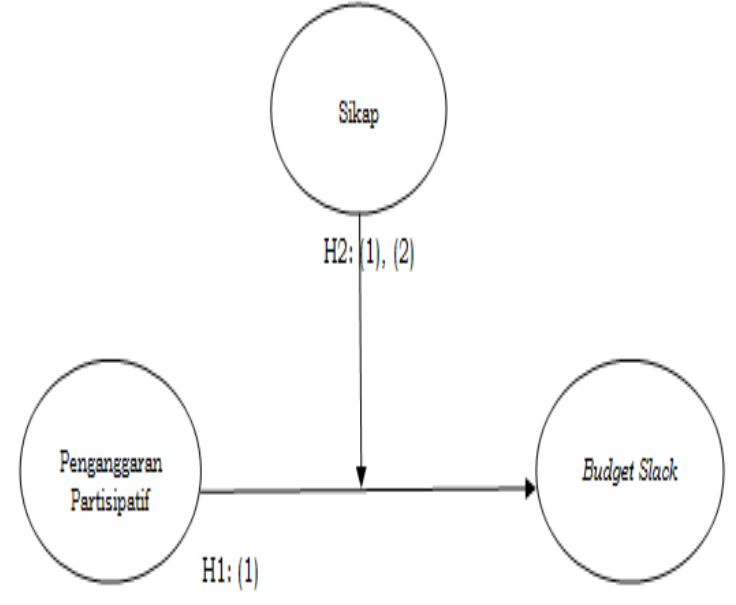

Gambar 1 Kerangka Konsep Penelitian

Keterangan:

Teori Agensi

Teori Planned Behaviour
Pengaruh Penganggaran Partisipatif Terhadap Budget Slack

Teori agensi menjelaskan bahwa bawahan (agent) dan atasan (principal) dalam menyusun dan mengimplementasikan anggaran didasarkan tanggung jawab untuk mencapai tujuan organisasi. Penganggaran partisipatif merupakan langkah penyusunan anggaran yang melibatkan berbagai pihak dalam proses penganggaran. Penganggaran partisipatif menjadi salah satu upaya yang dapat dilakukan dalam meminimalkan budget slack. Penganggaran partisipatif sebagai suatu proses dalam organisasi yang melibatkan para manajer dalam penentuan tujuan anggaran yang menjadi tanggung jawab dengan tujuan organisasi secara menyeluruh. Partisipasi bawahan akan meningkatkan kebersamaan, menumbuhkan rasa memiliki, inisiatif untuk menyumbangkan ide dan keputusan yang dihasilkan dapat diterima. Penelitian yang dilakukan oleh Dunk (1993) dan Young (1985) menemukan bukti empiris bahwa partisipasi bawahan mampu memengaruhi efektivitas dalam penyusunan anggaran sehingga dengan adanya keterlibatan individu cenderung akan mengurangi slack.

Dunk (1993) dan Merchant (1985) dalam hasil penelitiannya menunjukkan bahwa semakin besar keterlibatan individu dalam proses penganggaran maka tingkat partisipasi akan lebih tinggi dan mengakibatkan budget slack akan semakin rendah. Hal yang sama juga disampaikan oleh Desmiyawati (2009) yang meneliti penganggaran pada Pemerintah Daerah kabupaten Indragiri Hulu, bahwa penganggaran partisipatif berpengaruh negatif terhadap budget slack. Beberapa peneliti juga menemukan adanya pengaruh negatif penganggaran partisipatif terhadap budget slack diantaranya Fitri (2004), Kartika (2010) dan Onsi (1973).

Penelitian lainnya yang dilakukan oleh Lukka (1988) menunjukkan bahwa penganggaran partisipatif memiliki pengaruh positif terhadap budget slack. Sama halnya dengan Lukka (1988) melakukan pengujian pada sektor publik yang menemukan hasil bahwa partisipasi anggaran berpengaruh positif terhadap budget slack, artinya bahwa semakin tingginya partisipasi dalam penyusunan anggaran, maka budget slack juga akan semakin tinggi. Temuan empiris ini menunjukkan adanya inkonsistensi hasil penelitian karena disebabkan partisipasi anggaran yang tinggi sehingga mampu menurunkan budget slack. Namun, dengan hasil penelitian tersebut menjadikan besarnya keterlibatan individu dalam 
proses penyusunan anggaran malah akan semakin meningkatkan budget slack. Triadhi (2014), Kartika (2010), Pratama (2013), dan Mahadewi (2014) juga melakukan pengujian kembali atas pengaruh partisipasi anggaran terhadap senjangan anggaran, dan hasilnya mendukung Lukka (1988) yaitu semakin tinggi partisipasi anggaran, maka semakin tinggi pula senjangan anggaran yang tercipta.

Berdasarkan uraian tersebut, maka hipotesis yang diajukan adalah sebagai berikut :

H1 : Penganggaran partisipatif berpengaruh terhadap budget slack

\section{Sikap Memoderasi Pengaruh Penganggaran} Partsipatif terhadap Budget Slack

Sikap menunjukkan suatu disposisi untuk merespon secara positif atau negatif suatu perilaku. Sikap terhadap senjangan anggaran mengacu pada afeksi bawahan dalam menciptakan slack. Menurut TPB, sikap terhadap budget slack akan memengaruhi niat individu dalam menciptakan budget slack. Dengan kata lain, ketika bawahan memiliki sikap positif dalam proses penyusunan anggaran, maka senjangan anggaran yang terjadi akan rendah. Anggaran pemerintah daerah tentunya dibuat oleh aparat yang diberikan wewenang untuk menetapkan anggaran dari masing-masing SKPD. Aspek keperilakuan telah beberapa kali direkomendasikan oleh peneliti sebelumnya untuk dilakukan pengujian terhadap budget slack. Penelitian yang dilakukan Onsi (1973) yang memberikan rekomendasi penelitian selanjutnya tentang budget slack yang dipadukan dengan faktor perilaku. Dalam penelitiannya, Onsi (1973) melakukan pengujian terhadap faktor-faktor perilaku yang terlibat dalam penganggaran dengan tujuan untuk mengetahui sikap penyusun anggaran yakni kecenderungannya dalam melakukan tindakan senjangan anggaran. Hasil penelitian tersebut menunjukkan bahwa tindakan individu yang cenderung mengarah pada faktorfaktor perilaku yang positif dapat mengurangi senjangan anggaran.

Inti dari proses penganggaran adalah sesuatu memengaruhi sikap manajemen degan menetapkan standar kinerja dan mengendalikan pencapaian standar-standar tersebut, sehingga perencanaan anggaran menjadi serangkaian proses yang dilakukan individu dengan melalukan pengendalian atas standar-standar tersebut untuk dapat tercapai. Penelitian yang dilakukan Su dan Ni (2013) menemukan bahwa partisipasi anggaran dapat mengurangi senjangan anggaran melalui peningkatan sikap sehingga apabila individu memiliki niat positif dalam penyusunan anggaran maka senjangan anggaran akan berkurang. Kemudian, Huang dan Chen (2009) juga memberikan dukungan bukti empiris tentang pengaruh sikap terhadap senjangan anggaran. Temuannya menunjukkan bahwa persepsi positif sikap "attitude" individu, yaitu sikap baik yang dimiliki oleh individu dalam proses penyusunan anggaran dapat mengurangi terjadinya senjangan anggaran. Merchant (1981) juga menguatkan penelitian sebelumnya bahwa memang terdapat hubungan yang tinggi antara aspek perilaku dalam proses penyusunan anggaran terhadap budget slack atau senjangan anggaran. Berdasarkan penjelasan teori dan temuan penelitian tersebut di atas, setiap individu yang memiliki sikap positif dapat mendorong individu tersebut untuk meningkatkan partisipasi dalam penyusunan anggaran sehingga mengurangi budget slack.

Adanya keterlibatan individu dalam proses penyusunan anggaran seharusnya menjadi salah satu indikator yang dapat menurunkan budget slack. Sebagaimana dijelaskan dalam theory of planned behaviour (TPB) bahwa individu akan cenderung bertindak berdasarkan keyakinannya. Oleh karena itu, dengan adanya komunikasi dan kerja sama yang berasal dari sikap penyusun anggaran diharapkan mampu meningkatkan efektivitas pelaksanaan penyusunan anggaran yang tercermin melalui rendahnya budget slack.

Berdasarkan uraian tersebut, maka hipotesis yang diajukan adalah sebagai berikut :

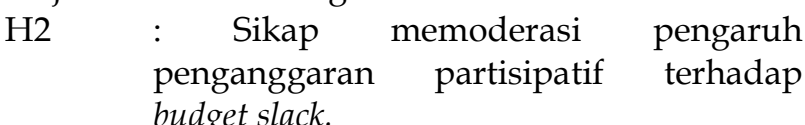

\section{METODE PENELITIAN}

Penelitian ini dilakukan untuk menguji pengaruh penganggaran partisipatif terhadap budget slack dengan sikap sebagai pemoderasi. Jenis penelitian ini adalah penelitian positivistic berupa explanatory research melalui pengujian hipotesis yang menjelaskan fenomena berbentuk hubungan antar variabel. Pengujian atau analisis penelitian menggunakan pendekatan kuantitatif dengan menggunakan alat statistik.

Penelitian ini dilakukan di Provinsi Sulawesi Tenggara. Pemilihan lokasi penelitian didasarkan pada fenomena budget slack yang dijelaskan dalam latar belakang penelitian, yaitu terlihat dari data potensi dan target pendapatan anggaran daerah yang mengindikasikan terjadinya budget slack di Pemda Provinsi Sulawesi Tenggara.

Populasi dalam penelitian ini adalah pejabat SKPD di Provinsi Sulawesi Tenggara dengan tugas 
atau kewenangan jabatan terdiri dari kepala SKPD (eselon II), kepala bagian/bidang (eselon III) sebanyak 216 orang (BKD Provinsi Sulawesi Tenggara). Metode analisis data yang digunakan dalam penelitian ini adalah Partial Least Square (PLS) dengan menggunakan program software SmartPLS 2.0. PLS merupakan sebuah pendekatan pemodelan kausal yang bertujuan memaksimumkan variansi dari variabel laten kriterion yang dapat dijelaskan (explained variance) oleh variabel laten prediktor (Sholihin dan Ratmono, 2013, hal.7).

\section{ANALISIS DAN PEMBAHASAN}

Kuisioner yang kembali berjumlah 136 orang, beberapa karakteristik responden berupa umur, jenis kelamin, pendidikan, dan jabatan disajikan pada tabel sebagai berikut:

Tabel 2. Karakteristik Responden

\begin{tabular}{|c|c|c|c|}
\hline \multirow[t]{2}{*}{ Karakteristik } & \multirow[t]{2}{*}{ Kriteria } & \multicolumn{2}{|l|}{ Responden } \\
\hline & & Frekuensi & Persen \\
\hline \multirow[t]{4}{*}{ Umur } & $<35$ & 2 & 1,47 \\
\hline & $35-40$ & 31 & 22,8 \\
\hline & $41-46$ & 68 & 50 \\
\hline & $>47$ & 35 & 25,73 \\
\hline \multirow{7}{*}{$\begin{array}{l}\text { Jenis } \\
\text { Kelamin } \\
\text { Pendidikan }\end{array}$} & Laki-laki & 102 & 75,00 \\
\hline & Perempuan & 34 & 25,00 \\
\hline & SMU & - & - \\
\hline & Diploma & 4 & 2,94 \\
\hline & Sarjana S1 & 65 & 47,79 \\
\hline & $\begin{array}{l}\text { Pascasarjan } \\
\text { a S2 }\end{array}$ & 66 & 48,52 \\
\hline & $\begin{array}{l}\text { Pascasarjan } \\
\text { a S3 }\end{array}$ & 1 & 0,73 \\
\hline
\end{tabular}

Sumber: Data primer diolah, 2016

Hasil uji validitas dapat dilihat pada Tabel 3.

Tabel 3. Rekapitulasi Hasil Uji Validitas Instrumen

\begin{tabular}{llll}
\hline Indikator & $\begin{array}{l}\mathrm{P} \text { - } \\
\text { Value }\end{array}$ & $\begin{array}{l}\text { Pearson } \\
\text { Correlation }\end{array}$ & Keterangan \\
\hline $\mathrm{X} 1.1$ & 0,00 & 0,924 & Valid \\
\hline $\mathrm{X} 1.2$ & 0,00 & 0,950 & Valid \\
\hline $\mathrm{X} 1.3$ & 0,00 & 0,976 & Valid \\
\hline $\mathrm{X} 2.1$ & 0,00 & 0,900 & Valid \\
\hline $\mathrm{X} 2.2$ & 0,00 & 0,781 & Valid \\
\hline $\mathrm{X} 2.3$ & 0,00 & 0,835 & Valid \\
\hline $\mathrm{Y} 1.1$ & 0,00 & 0,903 & Valid \\
\hline $\mathrm{Y} 1.2$ & 0,00 & 0,952 & Valid \\
\hline $\mathrm{Y} 1.3$ & 0,00 & 0,805 & Valid \\
\hline $\mathrm{Y} 1.4$ & 0,00 & 0,970 & Valid \\
\hline $\mathrm{Y} 1.5$ & 0,00 & 0,955 & Valid \\
\hline $\mathrm{Y} 1.6$ & 0,00 & 0,955 & Valid \\
\hline
\end{tabular}

\begin{tabular}{llll}
\hline Y1.7 & 0,00 & 0,972 & Valid \\
\hline
\end{tabular}

Sumber: Data Primer diolah, 2016

Dari Tabel 3 terlihat bahwa seluruh variabel memiliki nilai pearson correlation diatas 0,50 yang menunjukkan seluruh instrumen valid.

Hasil uji reliabilitas dapat dilihat pada Tabel 4.

Tabel 4. Rekapitulasi Hasil Uji Reliabilitas Instrumen

\begin{tabular}{llll}
\hline Variabel & $\begin{array}{l}\text { Cronbach's } \\
\text { Alpha }\end{array}$ & N & $\begin{array}{l}\text { Keteran } \\
\text { gan }\end{array}$ \\
\hline $\begin{array}{l}\text { Penganggaran } \\
\begin{array}{l}\text { Partisipatif } \\
(\mathrm{X} 1)\end{array}\end{array}$ & 0,973 & 3 & Reliabel \\
\hline Sikap (X2) & 0,937 & 3 & Reliabel \\
\hline $\begin{array}{l}\text { Budget Slack } \\
(\mathrm{Y})\end{array}$ & 0,982 & 7 & Reliabel \\
\hline
\end{tabular}

Sumber: data Primer diolah, 2016

Hasil analisis menunjukkan bahwa dengan menggunakan metode Cronbach's Alpha, seluruh variabel laten dalam penelitian ini reliabel, karena memenuhi cut off yang disyaratkan. Dengan demikian instrumen dari variabel yang digunakan memberikan hasil yang dapat dipercaya atau diandalkan.

Untuk menjelaskan bukti empiris yang menjadi temuan dalam penelitian ini, maka dilakukan pengujian hipotesis. Pengujian hipotesis dilakukan melalui pengujian koefisien jalur model persamaan struktural. Hasil pengujian hipotesis berdasarkan inner model (model penelitian) dari output PLS dengan estimasi parameter ditetapkan sebesar 95\% atau a $=0,05$, kemudian evaluasi pengaruh langsung dan pengaruh tidak langsung variabel independen (eksogen) terhadap suatu variabel dependen (endogen) dikatakan signifikan jika t- statistik $>1,960$ atau $p$ value $<0,05$. Hasil penelitian tersebut secara rinci dapat dilihat pada Tabel 5.

Tabel 5. Hasil Pengujian Hipotesis

\begin{tabular}{lcccc}
\hline $\begin{array}{c}\text { Pengaruh } \\
\text { antar } \\
\text { variabel }\end{array}$ & $\begin{array}{c}\text { Koefisi } \\
\text { en } \\
\text { jalur }\end{array}$ & $\begin{array}{c}\text { T- } \\
\text { statis } \\
\text { tik }\end{array}$ & $\begin{array}{c}\text { P- } \\
\text { value }\end{array}$ & Ket \\
\hline $\begin{array}{l}\text { Penganggara } \\
\text { n Partisipatif }\end{array}$ & & & & \\
$\rightarrow \quad$ Budget & -0.089 & 2.838 & 0.005 & $\begin{array}{l}\text { Signifik } \\
\text { an }\end{array}$ \\
Slack & & & & \\
\hline $\begin{array}{l}\text { Penganggara } \\
\text { n Partisipatif } \\
\text { * Sikap -> } \\
\text { Budget Slack }\end{array}$ & -0.245 & 11.52 & 0.000 & $\begin{array}{l}\text { Signifik } \\
\text { an }\end{array}$ \\
\hline Sikap $\rightarrow$ & 0.908 & 32.11 & 0.000 & Signifik \\
\hline
\end{tabular}




\begin{tabular}{ccccc}
\hline $\begin{array}{c}\text { Pengaruh } \\
\text { antar } \\
\text { variabel }\end{array}$ & $\begin{array}{c}\text { Koefisi } \\
\text { en } \\
\text { jalur }\end{array}$ & $\begin{array}{c}\text { T- } \\
\text { statis } \\
\text { tik }\end{array}$ & $\begin{array}{c}\text { P- } \\
\text { value }\end{array}$ & Ket \\
\hline Budget Slack & & 7 & & an \\
\hline
\end{tabular}

Ket : T-statistics : signifikan $\geq 1,96$ pada $a=0,05$

Sumber : Data Primer diolah, 2016

Pengujian hipotesis dan koefisien jalur pengaruh secara langsung yaitu pengaruh penganggaran partisipatif terhadap budget slack. Hasil pengujian pengaruh langsung antara variabel secara lengkap dapat dilihat pada Tabel 5.13. Hasil pengujian pengaruh penganggaran partisipatif terhadap budget slack dapat dibuktikan dengan nilai estimate koefisien jalur sebesar -0,089. Koefisien bertanda negatif memiliki arti hubungan antara penganggaran partisipatif dengan budget slack adalah tidak searah. Kemudian dapat dibuktikan pula dengan nilai T-statistics sebesar 2,838 $(>1,960)$ dengan taraf signifikan $a=0,05$ dan nilai $P$-Value menunjukkan 0,005. Hasil pengujian Hipotesis 1 yaitu penganggaran partisipatif berpengaruh negatif signifikan terhadap budget slack diterima, artinya keterlibatan individu (partisipan penyusun anggaran) yang tinggi dalam menyusun anggaran di satu SKPD akan mengurangi terjadinya budget slack. Adapun makna signifikan dapat dijelaskan bahwa kondisi ini menunjukkan semakin tinggi keterlibatan partisipan dalam menyusun anggaran maka penciptaan budget slack semakin rendah.

Hipotesis 2 yang dirumuskan adalah sikap memoderasi hubungan penganggaran partisipatif terhadap budget slack. Pembuktian sifat moderasi sikap didasarkan pada hasil uji koefisien jalur dari interaksi penganggaran partisipatif dan sikap terhadap budget slack (XxSIKAP->Y) yaitu sebesar 0,245 dengan nilai T-statistics 11,520 dan variabel moderasi sikap sebesar 0,908 adalah signifikan karena T-statistics sebesar 32,117 $(\geq 1,96)$ dan p-value sebesar 0,000 (lihat Tabel 5.13). Hasil ini menerangkan bahwa variabel sikap dapat menjelaskan terjadinya budget slack. Partisipan dengan tingkat keterlibatan kerja yang tinggi harus dibarengi dengan sikap yang positif karena sikap memengaruhi partisipasi dalam menentukan tinggi rendahnya budget slack yang terjadi. Dengan adanya sikap positif yang dimiliki partisipan mampu menyesuaikan emosi dan pikiran dalam menangani tekanan dan masalah dengan cara yang lebih sehat. Oleh karena itu, hipotesis 2 diterima.

Hasil penelitian ini membuktikan bahwa pengaruh penganggaran partisipatif terhadap budget slack signifikan (lihat tabel 5). Artinya bahwa budget slack dipengaruhi oleh tinggi rendahnya partisipasi dalam anggaran, sehingga untuk mengurangi slack yang terjadi dalam anggaran diperlukan partisipasi yang tinggi. Pejabat struktural di SKPD Provinsi Sulawesi Tenggara yang terlibat dalam penyusunan anggaran berpartisipasi dengan baik, terbukti dari tingginya tingkat keterlibatan partisipan dalam menyusun anggaran. Tingkat partisipasi partisipan dipengaruhi oleh beberapa perilaku partisipan yang aktif dalam memberikan opini atau sumbangan pemikiran, partisipan aktif dalam memberikan usulan dan pendapat tentang hal-hal yang berkaitan dengan anggaran tanpa diminta atasan yaitu tentang program-program yang akan diusulkan anggarannya dan juga aktif mengoreksi apabila ada hal-hal yang tidak logis yang tidak sesuai dengan anggaran sehingga anggaran bisa digunakan tepat sasaran.

Pada tabel 5 terlihat bahwa arah pengaruh yang terjadi adalah penganggaran partisipatif berpengaruh negatif signifikan terhadap budget slack, semakin tinggi partisipasi dalam anggaran maka bugdet slack yang terjadi semakin rendah. Hal ini disebabkan apabila partisipan semakin aktif berpartisipasi dalam menyusun anggaran yaitu aktif baik dalam memberikan opini atau sumbangan pemikiran, serta partisipan aktif memberikan usulan dan pendapat, juga mengoreksi apabila ada hal-hal yang tidak logis yang tidak sesuai dengan anggaran menyebabkan semakin cepat mengetahui prioritas alokasi anggaran sehingga produktifitasnya semakin meningkat. Selanjutnya apabila produktifitas meningkat maka penggunaan anggaran menjadi lebih tepat dan efisien.

\section{SIMPULAN}

Simpulan penelitian ini adalah budget slack yang terjadi di pemerintah daerah Provinsi Sulawesi Tenggara dipengaruhi oleh partisipasi dalam menyusun anggaran. Budget slack dapat dikendalikan dengan ikut berpartisipasi yang tinggi selama proses penyusunan anggaran. Bukti temuan ini menjelaskan bahwa semakin tinggi partisipasi dalam menyusun anggaran, budget slack yang tercipta akan semakin rendah. Partisipasi menunjukkan keterlibatan berbagai pihak yang duduk bersama dalam melakukan penyusunan anggaran. Keterlibatan tersebut akan meningkatkan rasa tanggungjawab dan tingkat kejujuran partisipan terhadap anggaran yang disusunnya sehingga tentunya akan mendorong para pimpinan SKPD untuk ikut bertanggung jawab dalam pencapaian anggaran secara efektif sehingga mengurangi budget slack. 
Dalam menyusun anggaran daerah, peran sikap sangat dibutuhkan bagi partisipan selama proses menyusun anggaran karena sikap dapat menentukan perilaku baik buruknya individu. Penyusunan anggaran yang melibatkan berbagai elemen struktural dalam satu SKPD ini meminimalisasi kepentingan-kepentingan partisipan dengan mencerminkan sikap yang positif dalam berpartisipasi menimbulkan rasa percaya dan motivasi bagi bawahan, sehingga budget slack dapat dikendalikan.

Studi ini memiliki beberapa keterbatasan yang pertama, berkaitan dengan metode pengambilan sampel penelitian. Dalam pengambilan sampel, peneliti tidak menggunakan penyampelan secara random (probabilitas) sehingga hasilnya tidak dapat digeneralisasi.

Kedua, terkait dengan rotasi pejabat struktural di satu SKPD dalam hal ini kepala SKPD dan kepala bagian/subbagian yang berkaitan dengan penyusunan anggaran, artinya bahwa dengan adanya pergantian pejabat struktural dalam SKPD dapat menyebabkan perubahan pada budaya organisasi dalam ruang lingkup SKPD tersebut, sehingga tentunya persepsi responden mengenai variabel yang diteliti akan berubah pula. Berdasarkan keterbatasan tersebut, untuk penelitian berikutnya disarankan agar menggunakan metode penyampelan secara random dan mempertimbangkan masa jabatan pejabat struktural di satu SKPD.

\section{REFERENSI}

Ajzen, I. (2005). Attitudes, personality, and behavior. McGraw-Hill Education (UK)

Anthony, R. N., \& V. Govindarajan. 2001. Management Controls Systems. Boston : Mc Graw-Hill Co.

Desmiawati, 2009. Pengaruh Partisipasi Anggaran Terhadap Senjangan Anggaran Dengan Komitemen Organisasi Sebagai Variabel Moderating. Pekbis Jurnal, Vol. 2, No. 2 July

Dunk, A. S. 1993. The Effect of Budget Emphasis and Information Asymmetry on the Relation Between Budgetary Participation and Slack, The Accounting Review, Vol. 68 No. 2, hal. 400-410.

Firmansyah, R. 2015. Pengaruh Partisipasi Anggaran dan Perilaku Penyusun Anggaran Terhadap Slack Anggaran
Dimoderasi Oleh Pemahaman Regulasi Anggaran. Thesis. Universitas Brawijaya. Malang.

Hafsah. 2005. Pengaruh Asimetri Informasi dan Komitmen Organisasi Terhadap Hubungan Anggaran dengan Kesenjangan Anggaran. Tesis. Universitas Sumatera Utara. Medan

Huang, C. L., \& Chen, M. L. 2009. The effect attitudes towards the budgetary process on attitudes towards budgetary slack and behaviors to create budgetary slack, Social Behavior and Personality, 37 (5), 661-672

Kartika, A. 2010. Pengaruh komitmen organisasi dan ketidakpastian lingkungan dalam hubungan antara partisipasi anggaran dengan senjangan anggaran. Kajian Akuntansi, Vol. 2 No. 1, hal 39-60

Lowe, A. E., \& Shaw, R. W., 1968, An Analysis of managerial biasing: Evidence from a company's budgeting process. Journal of Management Studies(October): 304-15

Lukka, K. 1988. Budgetary biasing in organizations: theoretical framework and empirical evidence. Accounting, Organizations and Society. 13 (3): 281-301

Mahadewi, S., \& Sagung, A. A. 2014. Pengaruh Partisipasi Penganggaran Pada Senjangan Anggaran dengan Asimetri Informasi dan Komitmen Organisasi Sebagai Pemoderasi. E-Jurnal Akuntansi Universitas Udayana, vol. 8.3 hal. $458-473$

Maskun, A. 2009. Analisis faktor etika, budaya organisasi, tekanan social, dan kapasitas individu terhadap budgetary slack (senjangan anggaran) (kajian perilaku eksekutif dalam proses penyusunan anggaran di Badan Koordinator Wilayah II Jawa Timur), Jurnal Aplikasi Manajemen, Volume 7, No. 1, Februari

Merchant, K. A. 1981. The Design of The Corporate Budgeting System : Inflences on Manajerial Behaviour and Performance. The Accounting Review. Hal : 813-828.

Noch, M. Y., 2006. Komitmen Organisasi dan Asimetri Informasi Sebagai Pemoderasi Pengaruh Partisipasi Anggaran Terhadap 
Senjangan Anggaran. Thesis. Universitas Brawijaya. Malang.

Nouri, H., \& Parker, R. J. 1996. The effect of organizational commitment on the relation between budgetary participation and budgetary slack. Behavioral Research in Accounting. 8: 74-90

Onsi, M. 1973. Factor analysis of behavioral variables affecting budgetary slack. The Accounting Review. 48 (3): pp; 535-548

Pratama, R. 2013. Pengaruh Partisipasi Anggaran Terhadap Senjangan Anggaran dengan Komitmen Organisasi dan Motivasi Sebagai Pemoderasi. Skripsi Fakultas Ekonomi, Universitas Negeri Padang

Rahim, S., Subroto, B., Rosidi, and Purnomoshidi, B. 2013. Gender differences on the influence of ethical judgment and moral reasoning toward budget slack behavior in publik sektor. Interdiciplinary Journal of Contemporary Research in Business, vol. 5. No. 2, June, pp. 227-241

Schiff, M., \& Lewin, A. Y., 1968, Where traditional budgeting fails. Financial Executive. May: 51-62

Su, C. C., \& Ni, F. Y. (2013). Budgetary participation and slack on the Theory of Planned Behavior. International Journal of Organizational Innovation (Online), 5(4), 91.

Sudarba, I. K. 2010. "Pengaruh Partisipasi Penganggaran, Komitmen Organisasi dan Ketidakpastian Lingkungan pada Senjangan Anggaran (Studi Kasus Pada Satuan Kerja Perangkat Daerah SeKabupaten Tabanan)" (tesis) Denpasar: Universitas Udayana

Supanto. 2010. "Analisis Pengaruh Partisipasi Penganggaran terhadap Budgetary slack dengan Informasi Asimetri, Motivasi, Budaya Organisasi sebagai Pemoderasi." (studi kasus pada politeknik negeri semarang)" (tesis). Semarang: Universitas Diponegoro.

Suprasto, B. 2006, Pengaruh interaksi partisipasi anggaran, informasi asimetris, dan penekanan anggaran terhadap slcak. Jurnal

Akuntansi dan Bisnis, 1(1).;75-
86

Triadhi, N. A. 2014. Pengaruh Preferensi Risiko, Etika dan Partisipasi Penyusunan Anggaran Pada Senjangan Anggaran Pendapatan di Pemerintah Provinsi Bali. EJurnal Ekonomi dan Bisnis Universitas Udayana, vol. 3.6, hal. 345-355

Young S. M. 1985. "Participative Budgeting: The Effect of Risk Aversion an Asymmetric Information on Budgetary Slack". Journal of Accounting Research. Autum 23: pp: 829-842.

Yuhertiana, I. 2009. Menggali Peluang Baru Penelitian di Ranah Akuntansi Keperilakuan Sektor Publik. Seminar Nasional Implementasi Sistem Manajemen Kualitas ISO 9001:2008. FE UPN “Veteran" Jatim 